\title{
Application of Green Design and Manufacturing in Mechanical Engineering: Education, Scientific Research, and Practice
}

\author{
Mengdi Gao ${ }^{1,2}$, Qingyang Wang ${ }^{1, *}$, Nan Wang ${ }^{1,3}$, Zhilin Ma ${ }^{1}$ and Lei Li ${ }^{2}$ \\ 1 School of Mechanical and Electronic Engineering, Suzhou University, Suzhou 234000, China; \\ mengdgao@163.com (M.G.); szxywn@126.com (N.W.); mazhilin018@163.com (Z.M.) \\ 2 School of Mechanical Engineering, Hefei University of Technology, Hefei 230009, China; lei_li@hfut.edu.cn \\ 3 School of Mechanical and Electronic Engineering, China University of Mining and Technology, \\ Xuzhou 221116, China \\ * Correspondence: qingy_wang@163.com; Tel.: +86-17805575586
}

check for updates

Citation: Gao, M.; Wang, Q.; Wang, N.; Ma, Z.; Li, L. Application of Green Design and Manufacturing in Mechanical Engineering: Education, Scientific Research, and Practice. Sustainability 2022, 14, 237. https:// doi.org/10.3390/su14010237

Academic Editor: Barbara Motyl

Received: 2 November 2021

Accepted: 18 December 2021

Published: 27 December 2021

Publisher's Note: MDPI stays neutral with regard to jurisdictional claims in published maps and institutional affiliations.

Copyright: (C) 2021 by the authors. Licensee MDPI, Basel, Switzerland. This article is an open access article distributed under the terms and conditions of the Creative Commons Attribution (CC BY) license (https:// creativecommons.org/licenses/by/ $4.0 /)$.

\begin{abstract}
Green design and manufacturing strategies are necessary to cope with the current resource, energy, and environmental problems of the manufacturing industry. To meet various enterprises' needs for green design and manufacturing, colleges and universities should integrate these concepts into their curricula. This study discusses the application of green strategies in the mechanical engineering field from the viewpoints of teaching, scientific research, and practical education. Based on its development and a basic connotation analysis, this study highlights the challenges and urgency of incorporating green concepts into teaching and research modules of mechanical engineering, as well as methods and implementation strategies to incorporate them in professional curricula using teaching method reform and the teaching and research integration method. An experimental training course of advanced manufacturing processes at the authors' institution was amended to emphasize the integrated application of green design and manufacturing. This integration not only enriches the field of mechanical engineering but also provides scientific research directions and methods to educators, along with new ideas to imbibe students with mechanical talents for their technical development. These efforts lay the foundation for the sustainable development of China's manufacturing industry.
\end{abstract}

Keywords: green design; green manufacturing; manufacturing industry; mechanical major; teaching reform

\section{Introduction}

The manufacturing industry is the backbone of the Chinese national economy, making it an important embodiment of industry competitiveness as well as the main economic guarantee of national security. The rapid development of the Chinese economy has brought about conflicts between the natural environment and the nation's need for resources, including the waste of resources caused by edge materials, debris, and decommissioned products, which occur within the manufacturing process, while the natural growth of available energy no longer meets the needs of the nation's economic development. Simultaneously, a large number of waste liquids, residues, and greenhouse gas emissions are also generated in the manufacturing process [1-3]. Therefore, green design and manufacturing concepts are rapidly gaining popularity in manufacturer development [4].

In recent years, various countries have successively implemented new green manufacturing strategies and policies. The United States pursued the Advanced Manufacturing Partnership Program (AMP v2.0); in 2019, the United States listed sustainable manufacturing (i.e., green manufacturing) as one of the key technologies needed to revitalize the manufacturing industry [5]. The European Union (EU) is currently implementing the EU Horizontal 2020 program and plans to invest 3818 million Euros into research on green manufacturing [6]. In October 2020, the Fifth Plenary Session of the 19th Central Committee 
of the Chinese Communist Party proposed the promotion of green development strategies, insisting on the concepts of green, silver, and golden mountains [7]. China has thus accelerated its promotion of green industry strategies and low-carbon development, thereby improving the quality and stability of its various ecosystems and has comprehensively improved the efficiency of its resource use. Therefore, green manufacturing strategies are necessary for realizing environmentally conscious goals.

The goal of talent cultivation in the mechanical engineering field within Chinese undergraduate colleges and universities is to train students with basic knowledge and application abilities in mechanical design, manufacturing, electromechanical engineering, and automation. Additionally, they are exposed to work that is closely related to the manufacturing industry, such as working with industrial robots, intelligent machinery, and other high-tech products, which allows them to effectively use their mechanical knowledge. The development of China's manufacturing industry cannot occur without the cultivation of these talents among aspiring students. Therefore, it is both urgent and necessary to integrate the principles of green design and manufacturing into the teaching and practice of mechanical qualifications in order for future workers in this field to cope with the current environmental problems faced by the manufacturing industry.

At present, some colleges and universities, situated both domestically and abroad, have integrated the concepts of green design and manufacturing into the teaching curricula of mechanical modules. Many higher education institutions are also offering related courses. Cheng Huanbo, a representative of the Nanjing Institute of Engineering, analyzed the necessity of establishing a green manufacturing course for mechanical engineering in colleges and universities and describes the training objectives and main teaching content of a green manufacturing course, the principles and teaching practice systems of integrating green manufacturing theory and methods into mechanical engineering qualifications, and the teaching of these theories and methods within this subject area [8]. Geng et al. [9] propose to cultivate interdisciplinary green manufacturing experts with a global perspective by adopting advanced education strategies and teaching methods in the mechanical manufacturing curriculum. This international approach to teaching requires universities to instill cutting-edge knowledge and engineering experience in students and hone their expertise in green manufacturing. Peng et al. [10] stated that more attention should be paid to the macro-control and supervision of green technologies in the Jiangsu manufacturing industry, as well as the optimization of environmental management and the strengthening of incentives for the promotion of green-innovative talents. Lin et al. [11] introduced green chemistry case studies into their laboratory courses. During the course of this experiment, students gained basic experience in electrochemistry and acquired analytical, critical thinking, and scientific literacy skills. Their results serve as a case study for green chemistry education, considering students' knowledge of the field of renewable and clean energy.

Abroad, Tseng [12], from the University of Texas, proposed the combination of green energy and manufacturing, as well as its integration into the teaching of manufacturing courses, to solve the challenges faced by this industry. Additionally, to help Kansas State University students understand green energy manufacturing, some content related to this subject was added to the "Introduction to Manufacturing Processes and Systems" course at Kansas State University (IMSE 250) [13]. Narayanan et al. [14] noted that the concept of green sustainability could be improved through manufacturing education. By attaching importance to the concept of green sustainability, they proposed a possible method to modify the content of the "Manufacturing Technology" course in graduate education.

The above research shows that the concept of green design and manufacturing has been integrated into the manufacturing process in all walks of life. When the modern mechanical industry is faced with a choice regarding the treatment of environmental resources, it is necessary to perform green design and manufacturing interventions. Various scientific researchers and research institutions are sparing no effort to perform the latest research work related to green manufacturing and have achieved fruitful research results. Such as the purpose of Xiong et al.'s work was to propose and develop a green manufacturing 
strategy for furniture enterprises, strengthening the development of green furniture products, improving the production mode of green furniture, and promoting the coordinated development of green production in the furniture industry [15]. In short, the study focused on green design and manufacturing of the furniture industry. In Jnr et al.'s work, a model was developed based on diffusion of innovation theory and sustainable life cycle process identified through a literature review; then, a survey method was employed. The results revealed that the internal and external characteristics influenced enterprise sustainability innovativeness [16]. Gaikwad et al. presented a systematic literature review and analysis concerning a possible framework, compatibility, drivers, and barriers for integrating three manufacturing strategies: Lean, Green, and Six Sigma [17].

However, it can be seen from both the teaching work of green design and manufacturing and the status quo of relevant teaching reform in colleges and universities (both domestic and international) that the integration teaching of green design and manufacturing and machinery is still insufficient. The mechanical engineering specialty in China only focuses on the teaching of product design theory and method, manufacturing technology, equipment, and engineering practice and training in the traditional sense of mechanical manufacturing. Green manufacturing is lagging in some developed countries in Europe and the United States in both application and teaching of theoretical methods. In China, only a small percentage of colleges and universities have implemented courses related to green manufacturing, and the theory and methods of green manufacturing have not been effectively integrated with professional teaching. Only by integrating green manufacturing into the mechanical engineering specialty can the deficiency of the existing manufacturing theory and method be circumvented, and the mechanical engineering talents be trained with green concepts for the successful implementation of sustainable development strategies by various enterprises. Our study specifically intended to provide a teaching reform method from the perspectives of course teaching, scientific research, and mechanical engineering practice to meet the demand for talents in the field of green design and manufacturing.

\section{Objects and Framework}

The machinery sector primarily provides production equipment to various industries and is also an important source of energy conservation and emission reduction, resulting in environmental pollution control. Statistical data indicate that the mechanical industry accounts for a large proportion of the energy consumption of the whole industry, with certain high-energy-consuming equipment causing high levels of pollution during their manufacture. Their demand for energy is so great that it is imperative to implement green design and manufacturing concepts. It is not only necessary to apply these concepts to all the equipment produced by the mechanical engineering sector but also to ensure that the operation cycle of such equipment is designed using these environmentally conscious concepts [18].

This is the core strategy for a transformation and upgrade of this sector, as well as a necessary requirement for the integration of the mechanical industry with green design concepts. Not only does the impact on the environment and its resources need to be considered, but also the constant improvement of the efficiency of using these resources [19]. This would involve the use of green materials to perform sustainable design and the adoption of green production technologies to ensure that the products are also energy saving, recyclable, and reusable, meaning that the overall construction machinery production cycle is comprehensively environmentally conscious. Only through this can the concepts of green design and manufacturing engulf the entire mechanical manufacturing process. This focused supervision and management will result in the improvement of pollution control and resource efficiency. Therefore, to adapt to the green development of the manufacturing industry, each enterprise is carrying out corresponding reforms, with the urgent demand for talents in green design and manufacturing concepts, as well as professional knowledge in this area. Therefore, in the training of mechanical professionals, whether 
it is in theoretical teaching or in engineering practice, each college and university should integrate the concept of green design and manufacturing into the knowledge development and professional skills training of their students.

The methodological framework is shown in Figure 1. This study introduces prevailing research of green design and manufacturing to show its key concepts, research direction, and future development. Considering the talent demand, cultivation method, and educational reform of the mechanical major in colleges and universities, the current problems and challenges of integrating green design and manufacturing concepts into mechanical education are discussed. The authors propose corresponding curriculum development methods and emphasize its application within the mechanical engineering field through the combination of green design and advanced manufacturing technologies within the practical teaching process.

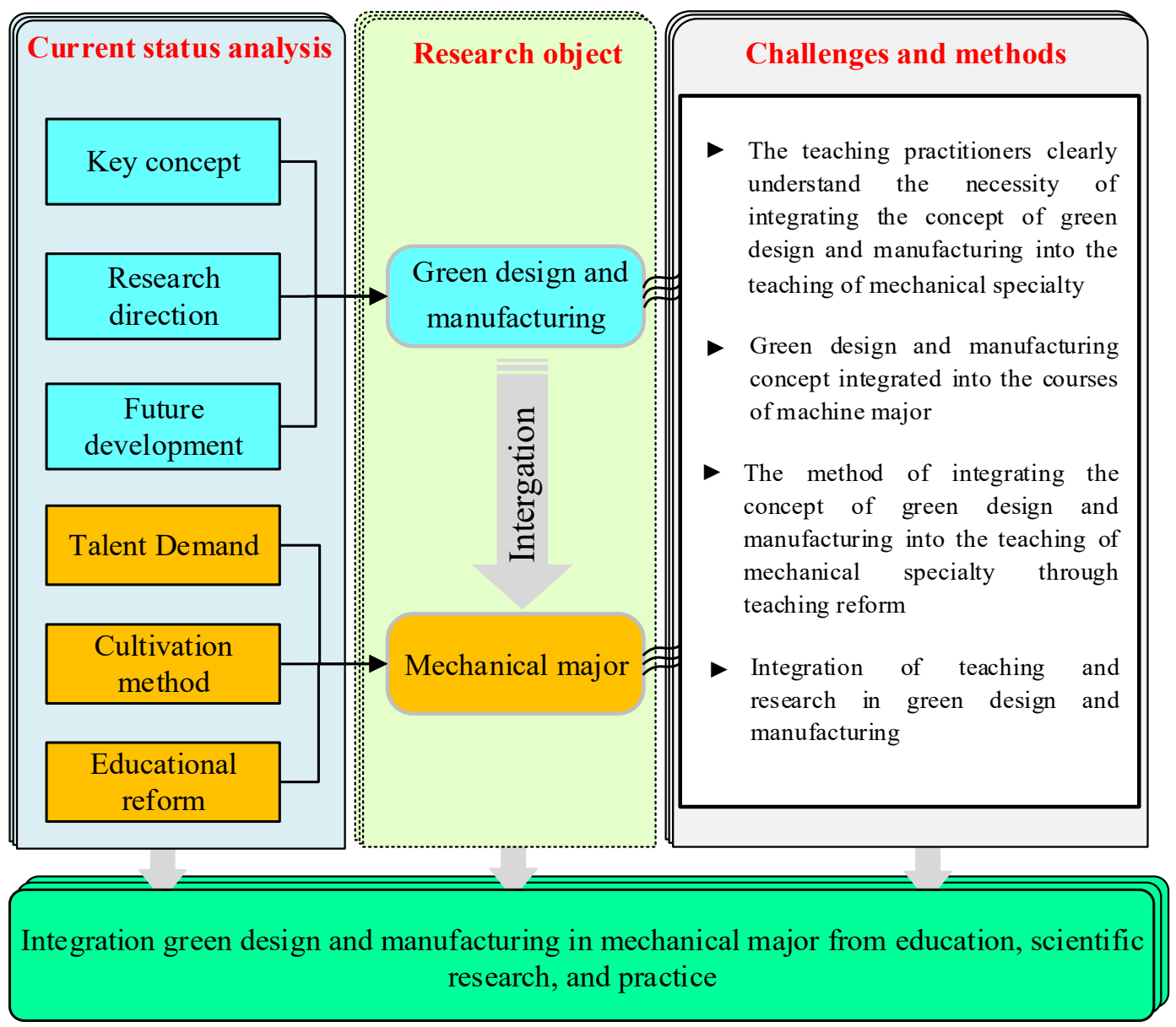

Figure 1. Methodological framework.

\section{Current Research on Green Design and Manufacturing}

Based on scientific studies and published papers of several major research organizations, both national and international, the main research direction of green design and manufacturing is based on the product life cycle, which can be divided into green design, green production, remanufacturing, and life cycle analysis and evaluation. The authors analyzed and described the current situation and main contents of these major research directions.

Green design is also known as ecological design (i.e., design for the environment) or environmentally conscious design [20,21]. Across the product's life cycle [22], its environmental attributes (detachability, recyclability, maintainability, reusability, etc.) should be considered as the primary design objectives to meet the requirements of environmental 
objectives and to ensure that function, service life, quality, and other requirements are met [23]. Green design involves redesign, connection technology, process design, knowledge engineering, computer integration, and artificial intelligence [24]. Its main content can be divided into the design application, method tool, and product data layers. The main research contents of each level are shown in Figure 2.

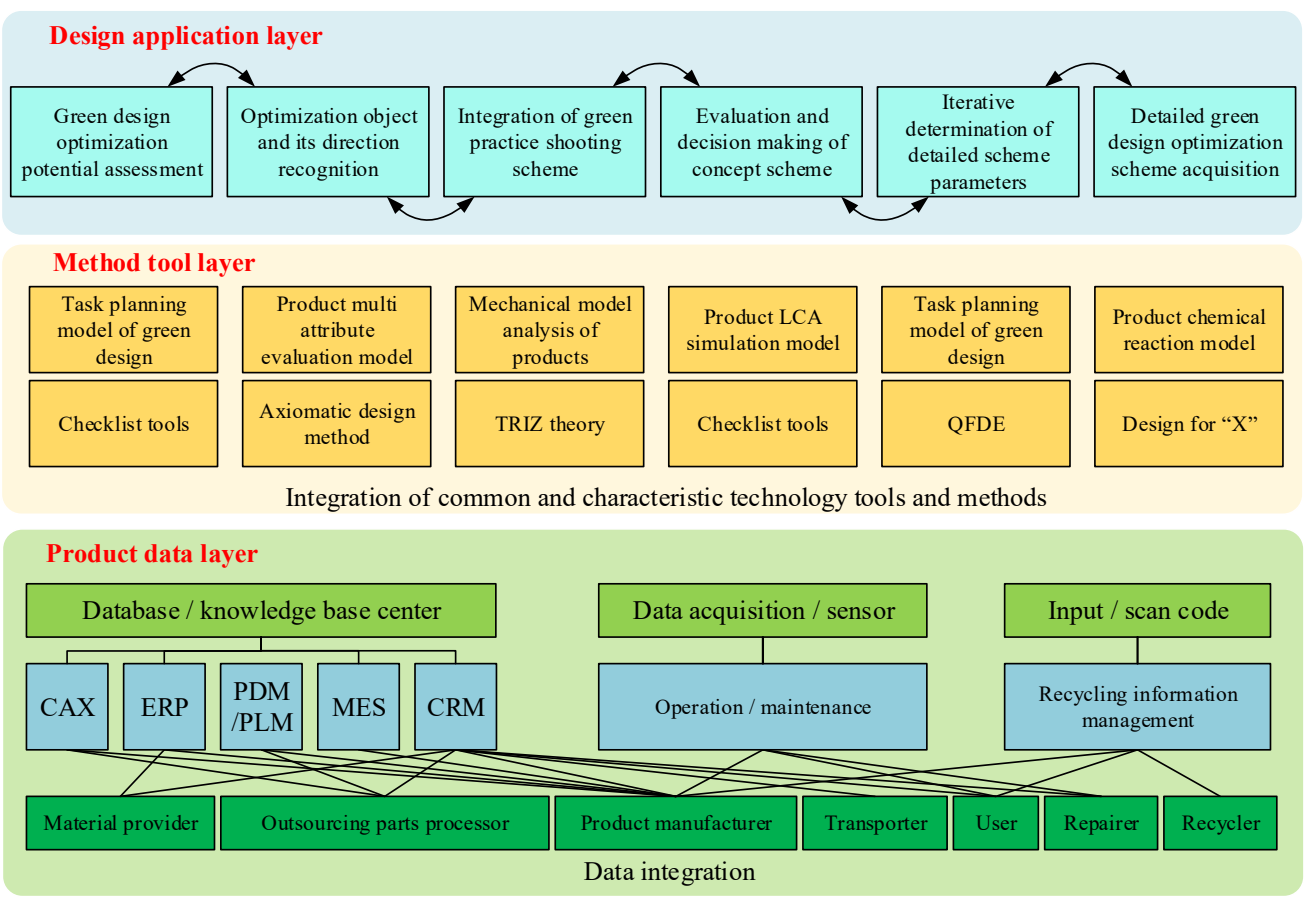

Figure 2. Hierarchy of green design research content.

Green production is a comprehensive measure that aims to promote energy-saving, consumption reduction, and pollution reduction while using management and technology to implement pollution control across the entire industrial production process so as to minimize the amount of pollutants created [25-27]. Production focuses on the manufacturing process, involving cutting, milling, forming, 3D printing, and other processes [28]. Related research includes energy consumption analysis and modeling, equipment energy-efficient design, important process parameter optimization, and process improvement [29,30]. Genetic algorithms, multi-objective optimization, neural network algorithms, energy consumption modeling analyses, machine learning models, and other methods are often used for process optimization [31,32].

Remanufacturing is a system engineering process that considers the life cycle management of product parts [33]. It involves refurbishing the product's original parts with remanufacturing molding technology (including high-tech surface engineering and other processing technologies) to restore their size, shape, and performance to form remanufactured products [34,35]. It mainly includes the reuse of remanufactured old parts on new products, combined with the recovery and improvement of the performance, reliability, and life of parts in their long-term use through remanufacturing, to ensure that the equipment reaches its best performance while resulting in minimum environmental pollution, maximum resource use, and minimum input cost. Remanufacturing engineering is regarded as both a supplement to and the current development of advanced manufacturing technologies, in addition to being a new industry with great potential in the 21st century [36-38]. The remanufacturing process generally includes eight steps: product cleaning, target object disassembly, cleaning, testing, remanufacturing parts classification, remanufacturing technology selection, remanufacturing, and inspection [39,40]. The key technologies and processes of remanufacturing are shown in Figure 3. 


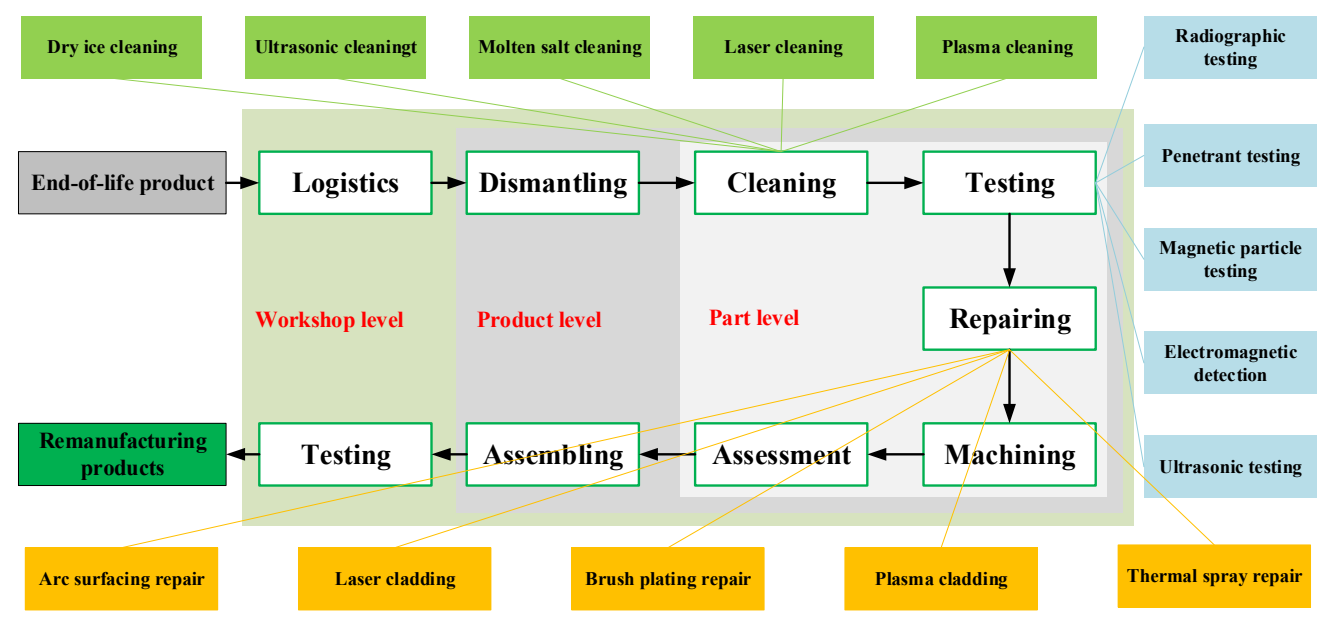

Figure 3. Remanufacturing flow and its main technologies.

Life cycle assessment (LCA) is a method to evaluate the overall environmental impact of a product or a class of facilities from its inception to the end of its use [41]. It observes the relevant problems from regional, national, and global levels, as well as that of sustainable development. Therefore, using LCA to evaluate the alternatives of different products or facilities allows for choosing the optimal solution to these problems. At present, the research status of product life cycles can be divided into three levels: theory, methods, and application. The specific content of these levels is shown in Figure 4. At the theoretical level, the research mainly focuses on the database, evaluation methods, and information systems, while the life cycle method focuses on the research of socially sustainable development, environmental management, and advanced technologies. The final application level involves the realization of the green certification of enterprises, parks, and products, as well as getting industries to form green supply chains, production processes, and production modes to realize the sustainable development of clean production processes in the field of machinery manufacturing $[42,43]$.

\begin{tabular}{|c|c|c|}
\hline \multicolumn{3}{|c|}{ Theory } \\
\hline Data quality & Evaluation method & Information system \\
\hline $\begin{array}{l}\text { Not match the domestic } \\
\text { market } \\
* \text { Accuracy is not high } \\
* \text { Data missing }\end{array}$ & $\begin{array}{l}* \text { Multiple integration methods } \\
* \text { Multi attribute integration } \\
* \text { Algorithm optimization }\end{array}$ & $\begin{array}{l}\text { * Not enough } \\
\text { commercialization } \\
\text { * The function is not perfect } \\
\text { * The universality is not strong }\end{array}$ \\
\hline \multicolumn{3}{|c|}{ Method } \\
\hline Social sustainable development & Environmental management & Advanced technique \\
\hline $\begin{array}{l}\text { Waste management } \\
* \text { Alternative development } \\
\text { - Green product development }\end{array}$ & $\begin{array}{l}\text { * Cleaner production audit } \\
\text { *nvironmental label } \\
\text { certification } \\
\text { * Environmental policy making }\end{array}$ & $\begin{array}{l}* \text { Dynamic data extraction } \\
* \text { Dynamic modeling } \\
* \text { Dynamic evaluation }\end{array}$ \\
\hline \multicolumn{3}{|c|}{ Application } \\
\hline Green certification & Enterprise application & Cleaner production \\
\hline $\begin{array}{l}* \text { Green park certification } \\
* \text { Green factory certification } \\
* \text { Green product certification }\end{array}$ & $\begin{array}{l}* \text { Green supply chain } \\
* \text { Green production process } \\
* \text { Green product production }\end{array}$ & $\begin{array}{l}* \text { Clean energy } \\
* \text { Cleaning products } \\
* \text { Cleaner production process }\end{array}$ \\
\hline
\end{tabular}

Figure 4. Research status of life cycle analysis. 
The main research directions and methods of green design and manufacturing mentioned above provide specific points for its integration into the teaching of mechanical specialty, point out the direction of talent training of mechanical specialty, and provide a reference and basis for the future development direction of mechanical specialty.

\section{Integration of Green Design and Manufacturing Concepts into Mechanical Engineering Education}

\subsection{Green Design and Manufacturing Concepts Integrated into Mechanical Engineering Courses}

As guided by the public and subject to basic courses of mechanical engineering qualifications, the concept of green design and manufacturing has been gradually introduced into the basic and professional modules of engineering technology, with the characteristic courses of the green design and manufacturing specialty being implemented. Comprehensive and innovative experiments have been designed to consolidate the learning of green design and manufacturing concepts.

Regarding the course content, the subject of green production was used to train students on how to maximize the saving of resources and energy and to reduce environmental pollution across the life cycle of mechanical and electronic products. It was a required course aimed at cultivating students' awareness of the environment, as well as introducing green production methods to them. During the teaching of this subject, comprehensive applications and summaries of students' knowledge about optional courses, combined with their use of new technologies and products, have enabled the students to consider resource use, recycling, environmental pollution, and other issues more comprehensively, which can be embodied in the following ways (Figure 5).

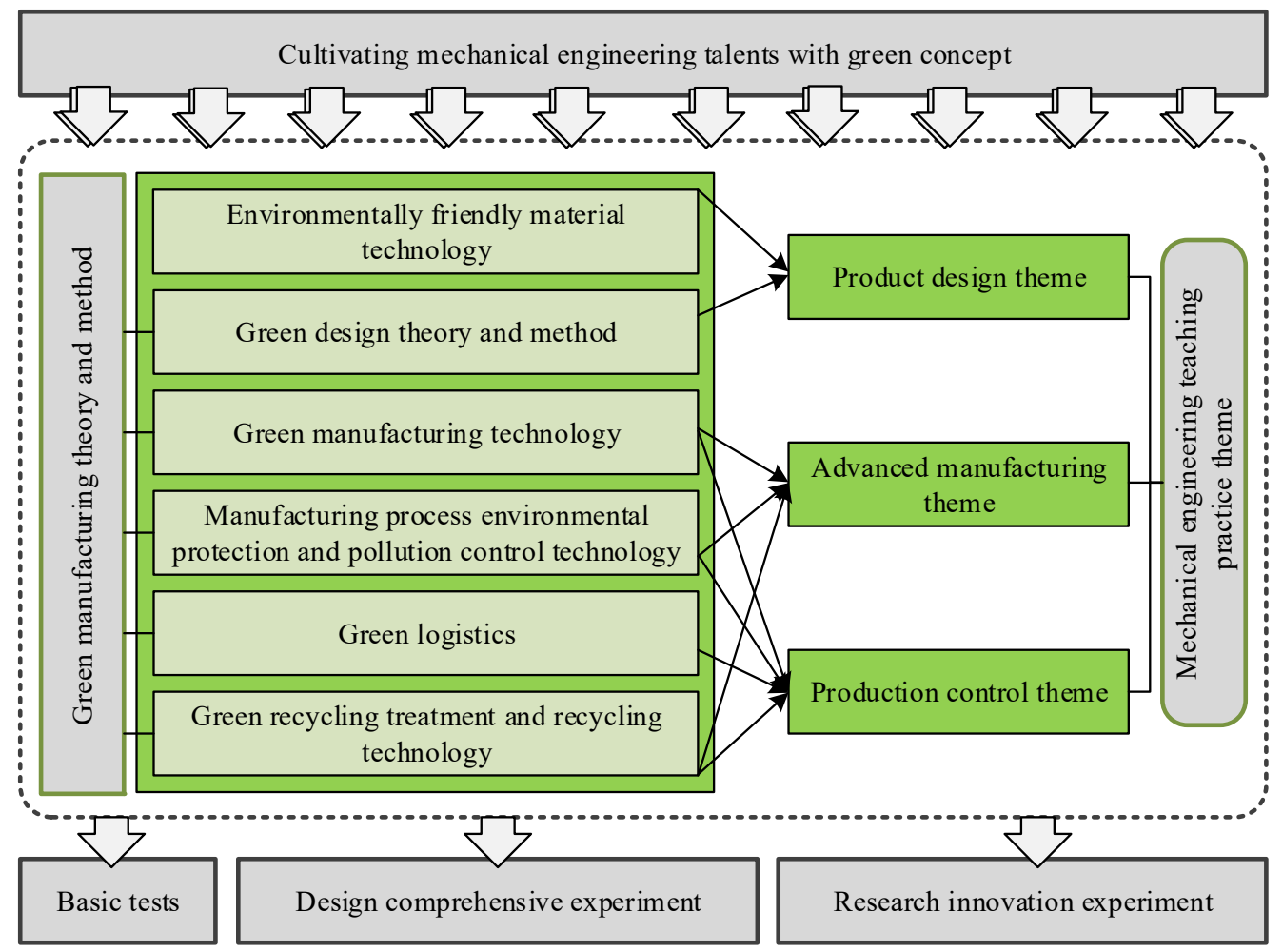

Figure 5. Integration of green manufacturing theory and methods.

In the "Mechanical Design" course, the green design theory and methods involving disassembly, recycling, energy saving, and low-carbon designs, among others, could be integrated into this course. In total, $80 \%$ of product performance is determined by the design stage. Green design theory and methods have been integrated into the teaching of mechanical design; thus, students form an awareness of integrating these concepts into the design of the product itself. For example, in the module on gear and shaft design, the 
recycling and remanufacturing process at the end of product life cycles is taught; additionally, in the chapter on mechanical structure design, disassembly and recyclability are both fully explained. To satisfy the needs of product use, both economic and environmental factors are considered to achieve an optimal design of the product's structure. Concerning a mechanical system design, the concept of energy saving is outlined, which teaches the students methods of product designs that optimize this feature.

Green material reduction technology and green additive manufacturing technology can be incorporated in the "Mechanical Manufacturing" course. With the goal of making the manufacturing process environmentally sustainable, various green manufacturing methods, including the green heat treatment process, the dry cutting process, recycling and remanufacturing technology, and low-carbon manufacturing technology, should be introduced to the students. The manufacturing process can be divided into the technical equipment, process route, and collaborative scheduling layers. Through the incorporation of green technology units that are involved in different manufacturing levels into the teaching of mechanical engineering technologies, students can master both the traditional manufacturing technologies, as well as come to understand the key technologies of the green manufacturing process, which lays a theoretical basis for their future implementation of environmentally cleaner production.

In the "Material Forming" course, the selection of new environment-protecting materials, the use of retractable and degenerate materials, the identification and control of forming process energy, as well as other relevant content should be incorporated in this course. Enhancing students' awareness of green environmental materials, instilling in them a knowledge of energy optimization within the material forming process, and giving them an environmentally focused awareness of material selection, packaging structure optimization, and material forming are all important facets. For example, to guarantee the strength and safety performance of all products, the equipment's weight should be lowered as far as possible to improve its power and reduce its fuel consumption. Lightweight materials, such as aluminum, magnesium, ceramics, plastics, fiberglass, or carbon fiber composites, are preferred.

The "Systems Engineering" course should enable students to master the analysis methods of the product life cycle; help them to analyze the environmental impact of products during production; teach them the use and waste processes with software tools; and help them to understand the entire life cycle process, from production, use, recycling, and reuse.

Finally, concerning the "Logistics Management" course, the theories and methods of green supply chain management and reverse supply chain management need to be increased by adding inventory control, using reverse logistics network planning, and using production planning to provide students an understanding of the life cycles of products.

\subsection{Implementation Method}

In this process, correct design and manufacturing ideas and the cultivation of the ability to solve practical problems using theoretical knowledge should be established. Additionally, students need to understand the relevant concepts, basic theories, thinking methods, and basic principles of green manufacturing. Furthermore, training on the basic skills of green manufacturing should be conducted. Next, through the use of targeted experiments, students' perceptual knowledge can be enhanced, allowing them to master the methods of combining green concepts with traditional design theory for product design and the manufacturing process. The specific implementation method includes the following aspects.

(1) Flexible teaching content: The technical systems of green manufacturing should be combined with design, manufacture, and production management in the teaching of mechanical engineering, with the product's life cycle as the main focus, while including this in the different courses of this qualification; that is, the different integration points of green manufacturing's content should be selected and connected in an orderly manner; 
(2) The variety of teaching methods: This involves inviting experts in green production and engineering who are personally engaged in research in such enterprises to conduct a series of lectures to improve students' understanding of the development of green production, as well as to help them understand the application of the theory and methods of environmental sustainability in production practice. Regarding professional knowledge, a practice and production internship with a specific project should be conducted to help promote an understanding of the application process of green production concepts, thereby strengthening students' perception of this subject. The teaching content of green production must follow the instant principle; that is, students should learn of the latest theoretical results and methods, in real-time, during the teaching process, and the teaching content should be in line with the most recent developments in green production. For example, the subjects in this qualification should include the latest theories and methods, such as low-carbon design, low-carbon production, and life cycle simulation;

(3) Diversified principles: These need to be covered as part of the course training, with optional courses for green manufacturing content being offered, such as those on energy saving and emission reduction technologies in the manufacturing industry, as well as designs based on environmental awareness, non-destructive testing, life cycle engineering, green-innovative designs, metal and non-metal regeneration techniques, and other optional courses. It is necessary to establish these optional courses in the green manufacturing field to support the teaching of this subject area. Proper settings for the proposed optional courses will strengthen students' learning and understanding of green manufacturing theory and methods;

(4) Integrating green manufacturing theories and methods into teaching practice: Increasing the analysis experiments of material use and resource consumption in basic experiments will help to guide students' understanding of the importance of this integration, including concepts such as recycling carbon fiber reinforced resin matrix composites with supercritical fluid, as well as analyzing the effects of temperature, pressure, and time on recovery efficiency and quality. In the design comprehensive experiment, green product development is conducted by combining green design theory and methods with more innovative design techniques; from this, the software frame for analyzing the performance of green products is created, the module function is analyzed, and the application process of product green design theory and methods is understood. In an experiment based on research innovation, the latest theory and achievements of the green manufacturing industry are discussed, such as the greening of the manufacturing process and the design of integrated coolant-free processing devices.

\subsection{Integrating Teaching and Research}

The integration of green design methods, manufacturing concepts, main research directions, and scientific progress of green manufacturing into mechanical engineering education can promote the development of higher education and research on this subject. Additionally, exploring different disciplines within the field through education and literature is necessary to comprehensively understand green manufacturing at all possible levels. Research projects support undergraduate training through the promotion of professional and project-based teaching while achieving the inclusion of green manufacturing theory and methods in all disciplines across education and practice innovation. This can be achieved through the following:

(1) Education should be promoted using the latest scientific research. The scientific research achievements of green manufacturing should be introduced in the teaching content, curriculum design, and graduation design so that students can participate in completing the study goals of related scientific research projects, thereby improving their cognitive abilities around green manufacturing;

(2) The skills and knowledge of teaching staff also need to be considered. Mechanical engineering teachers should understand and master the theory, technology, and methods 
of green manufacturing, in addition to improving the educational level of green manufacturing subjects by inviting experts in the field to give lectures;

(3) To improve students' cognitive abilities around green manufacturing, and to strengthen their conceptions of it, various green manufacturing science and technology innovation competitions are currently held. In the future, the cultivation of green manufacturing talents should focus on the three fields of professional technology, business management, and skills while also including the three levels of technical equipment, process route, and collaborative scheduling levels to cultivate mechanical engineering talents with green concepts.

\section{Application of Green Design and Manufacturing Combined with Advanced Manufacturing Technologies}

\subsection{Practical Teaching Reform Means}

At present, the authors' institution has implemented additive manufacturing (3D printing) related experimental training courses. The teaching goal is to assist students in mastering the basic theoretical knowledge of 3D printing, learning the operation of multiple 3D modeling software, practicing the operation of related layered processing software, and learning the operation of related 3D printers while working in a team setting to complete the corresponding tasks. The final training task of this course involves the use of different additive manufacturing equipment to process a simple mechanical solid part (Figure 6) with the shape and size parameters of the selected parts shown in Table 1. To integrate the concepts of green design and manufacturing into the teaching of this course, an experimental task has been incorporated to clarify the energy consumption characteristics and equipment energy efficiency of different additive manufacturing equipment that are processing the same workpiece.

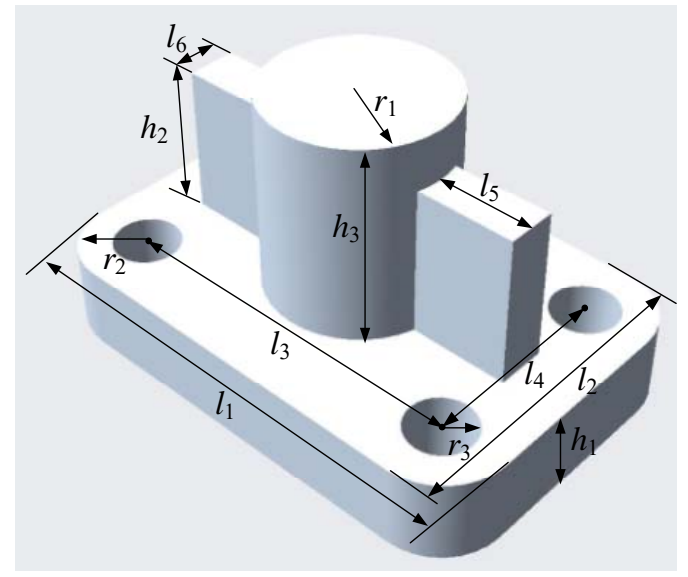

Figure 6. Models of additive manufacturing parts.

Table 1. Shape and size parameters of the processed additive manufacturing parts.

\begin{tabular}{ccccccc}
\hline Shape and size parameters & $\begin{array}{c}l_{\mathbf{1}} \\
(\mathbf{m m})\end{array}$ & $\begin{array}{c}l_{\mathbf{2}} \\
(\mathbf{m m})\end{array}$ & $\begin{array}{c}l_{\mathbf{3}} \\
(\mathbf{m m})\end{array}$ & $\begin{array}{c}l_{\mathbf{4}} \\
(\mathbf{m m})\end{array}$ & $\begin{array}{c}l_{\mathbf{5}} \\
(\mathbf{m m})\end{array}$ & $\begin{array}{c}l_{\mathbf{6}} \\
(\mathbf{m m})\end{array}$ \\
\hline Value & 40 & 28 & 28 & 16 & 7 & 4 \\
\hline Shape and size parameters & $\begin{array}{c}\boldsymbol{r}_{\mathbf{1}} \\
(\mathbf{m m})\end{array}$ & $\begin{array}{c}\boldsymbol{r}_{\mathbf{2}} \\
(\mathbf{m m})\end{array}$ & $\begin{array}{c}r_{3} \\
(\mathbf{m m})\end{array}$ & $\begin{array}{c}\boldsymbol{h}_{\mathbf{1}} \\
(\mathbf{m m})\end{array}$ & $\begin{array}{c}\boldsymbol{h}_{\mathbf{2}} \\
(\mathbf{m m})\end{array}$ & $\begin{array}{c}\boldsymbol{h}_{3} \\
(\mathbf{m m})\end{array}$ \\
\hline Value & 8 & 6 & 3 & 6 & 12 & 16 \\
\hline
\end{tabular}

During training, after the parts are modeled and sliced, according to the model processing software corresponding to the three different additive manufacturing equipment devices, the students set the parameters of the corresponding parts and then import them into the corresponding equipment for forming. At present, the " $3 \mathrm{D}$ printing application 
innovation center" has three kinds of additive manufacturing equipment: the JGAURA-A8S (FDM experimental equipment), the UNIONTECH-RS3000 (SLA experimental equipment), and the BLT-S210 (SLM experimental equipment). The power meter of the AWS2103S Plus is used to measure the real-time power consumption of this additive manufacturing equipment when processing parts (Figure 7). The energy consumption of the three additive manufacturing equipment pieces, each of which is processing the same part, is obtained through corresponding data processing. The test results are shown in Table 2.

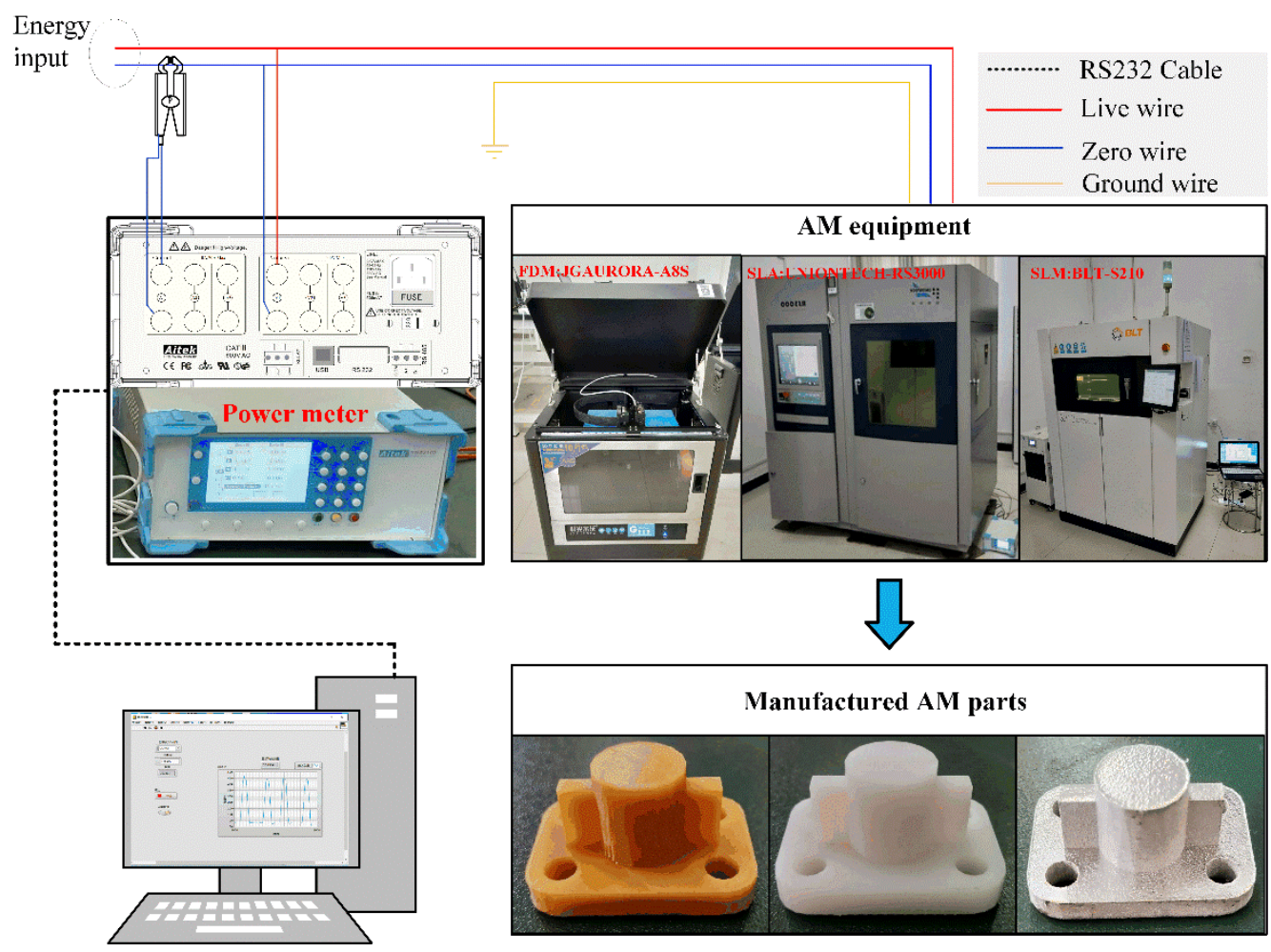

Figure 7. Schematic of the experimental testing system.

Table 2. Experimental energy consumption and equipment energy efficiency under different additive manufacturing modes.

\begin{tabular}{cccc}
\hline Processing Method & $\begin{array}{c}\text { Total Energy Consumption } \\
\text { of Equipment } E_{j}(\mathbf{k J})\end{array}$ & $\begin{array}{c}\text { Forming Energy Consumption } \\
\text { of Part } E_{\text {part- } j}(\mathbf{k J})\end{array}$ & $\begin{array}{c}\text { Energy Efficiency of } \\
\text { Equipment } \boldsymbol{\eta}_{j} \%\end{array}$ \\
\hline FDM & 1361.763 & 1222.908 & $89.80 \%$ \\
SLA & 2316.870 & 1840.781 & $79.45 \%$ \\
SLM & $28,144.673$ & $23,669.116$ & $84.10 \%$ \\
\hline
\end{tabular}

By analyzing the energy consumption of the three kinds of equipment used to process the same part, students discovered that the SLM equipment has the greatest total energy consumption and part forming energy consumption, followed by the SLA, and then the FDM process, with the total energy consumption of the SLM equipment and its part forming energy consumption being more than 20 times that of the FDM, respectively. This is because the material of the SLM process is metal powder, meaning that it is completely melted down and then deposited, resulting in it consuming more energy. Therefore, the SLM undergoes a high energy consumption process.

By comparing the three types of equipment, students could discover that their energy efficiency is approximately $80 \%$, with the energy efficiency of the FDM equipment being the highest at nearly $90 \%$, and the energy efficiency of the SLA equipment being the lowest, which is because of the different energy consumption of the auxiliary units of these equipment types. The FDM equipment has the advantages of having a simple structure 
and fewer energy-consuming components in its control and auxiliary units, meaning that it has the highest energy efficiency. Furthermore, the SLA equipment's auxiliary unit has many energy-consuming components and a complex control system, which leads to high auxiliary energy consumption and low energy efficiency overall.

\subsection{Discussion of Practical Teaching Reform}

The rapid development of any technology cannot occur without the appropriate talent training being imparted to its main participants. At present, undergraduates majoring in mechanical engineering in China primarily learn about product design theory and methods, manufacturing technologies and equipment, engineering practice training, and other content from the traditional mechanical manufacturing field. The subject of green design and manufacturing is slightly insufficient in both theoretical and practical teaching; although some colleges and universities have offered courses related to this subject, it has still not been effectively integrated with the current teaching modalities. Therefore, to adapt to the modern teaching environment and the requirements of enterprises for green production-related talents, it is urgent to train students in high-quality skills, providing them with a wide range of knowledge in this subject area. Only when green theory and methodologies are integrated into the teaching of major mechanical projects can the existing problems in this industry be effectively compensated with sustainable development.

The development of the above training content not only enables students to understand and master the latest developments in advanced manufacturing technologies but also integrates the concept of green manufacturing into their education and training so that they can clearly describe the energy consumption tests of different equipment types, as well as the analysis methods of industrial energy consumption characteristics, thus enriching the overall training content. These results provide a method and experimental basis for the quantification of additive manufacturing energy consumption, energy conservation, and emission reduction while also laying a foundation for students to engage in scientific research in the future.

\section{Conclusions}

To adapt to the green development of the manufacturing industry and to meet the needs of manufacturing enterprises for green design and manufacturing talents, this study analyzed the emergent developmental processes of green design and manufacturing. Based on the current teaching reform of concepts of green design and manufacturing being integrated into the teaching curricula, the problems and challenges faced by current manufacturing and talent demand have been discussed. By formulating the basic connotation of these concepts, analyzing the current research body and its main direction in terms of green design and manufacturing, and acknowledging the urgent need for an integration of green design and manufacturing into the teaching and research of mechanical qualifications, this study puts forward novel methods of integrating this concept into the curriculum of mechanical engineering, the implementation mode of this teaching reform, and the integration method of these concepts into both teaching and scientific research. Combined with the integration of green manufacturing concepts in advanced manufacturing technology experiments and training courses at the authors' institution, the integration application of green design and manufacturing in the teaching and scientific research of mechanical engineering is possible.

The application of green design and manufacturing in the teaching, scientific research, and practice of the mechanical engineering qualification not only enriches the current curriculum of this course from the perspective of teaching reform but also provides scientific research directions and methods for most university teachers, along with new ideas for the realization of the training goals of mechanical talents oriented to the development of enterprises and current technology. Regarding students' self-development, it lays the foundation for students engaging in scientific research at a later stage. In the future, this achievement can be extended to be applied to talent training and curricula reform of other 
related majors. The difficulty is that this is a gradual process of reform that may take a long time to achieve.

Author Contributions: Conceptualization, M.G. and Q.W.; methodology, Z.M.; investigation, N.W.; data curation, Z.M.; writing — original draft preparation, M.G.; writing—review and editing, Q.W. and L.L.; funding acquisition, M.G., Q.W. and L.L. All authors have read and agreed to the published version of the manuscript.

Funding: This research was funded by the National Natural Science Foundation of China (No. 52005146), the Natural Science Foundation of Anhui Province (Nos. 2008085QE265 and 2008085QE232), the Domestic Visiting and Study Program for Outstanding Young Backbone Talents in Colleges and Universities (No. gxgnfx2021151), School level key project of natural science of Suzhou University (2019yzd03) and the Quality Engineering Project (Nos. szxy2020sfzx02, szxy2020szkc04, and szxy2020jyxm05).

Institutional Review Board Statement: Not applicable.

Informed Consent Statement: Not applicable.

Data Availability Statement: Not applicable.

Conflicts of Interest: The authors declare no conflict of interest.

\section{References}

1. Yeong, W.Y.; Chua, C.K. A quality management framework for implementing additive manufacturing of medical devices. Virtual Phys. Prototyp. 2013, 8, 193-199. [CrossRef]

2. Woo, W.-S.; Kim, E.-J.; Jeong, H.-I.; Lee, C.-M. Laser-assisted machining of Ti-6Al-4V fabricated by DED additive manufacturing Int. J. Precis. Eng. 2020, 7, 559-572. [CrossRef]

3. Ahn, D.-G. Direct metal additive manufacturing processes and their sustainable applications for green technology: A review. Int. J. Precis. Eng. 2016, 3, 381-395. [CrossRef]

4. Ping, L.X. Application of green concept in mechanical design and manufacture. In Proceedings of the 2017 3rd International Conference on Energy, Environment and Materials Science (EEMS), Singapore, 28-30 July 2017; Northwestern Polytechnical University: Singapore, 2017.

5. Executive Office of the President's Council of Advisors on Science and Technology. Report to the President on Capturing Domestic Competitive Advantage in Advanced Manufacturing. Available online: https://www.whitehouse.gov/sites/default/files/ microsites/ostp/pcast_amp_steering_committee_report_final_july_27_2012.pdf (accessed on 11 December 2021).

6. Reillon, V. EU Framework Programmes for Research and Innovation. Available online: https://op.europa.eu/en/publicationdetail/- / publication/7857e8f0-a4c1-11e7-837e-01aa75ed71a1/language-en (accessed on 10 December 2021).

7. Consulate-General of The People's Republic of China. Communiqu of the Fifth Plenary Session of the 19th CPC Central Committee. Available online: http:/ / cpc.people.com.cn/gb/n1/2020/1029/c64094-31911510.html (accessed on 11 December 2021).

8. Cheng, H.; Yang, L.; Jian, W. Teaching exploration of integrating green manufacturing theory and methods into mechanical engineering specialty. China Mod. Educ. Equip. 2018, 285, 56-61.

9. Geng, D.L.; Gan, Y. Internationalizing instructional methodology for postgraduates in green manufacturing. In Proceedings of the 6th International Conference on Electronic, Mechanical, Information and Management Society (EMIM), Shenyang, China, 1-3 April 2016; pp. 66-70.

10. Peng, B.H.; Zheng, C.Y.; Wei, G.; Elahi, E. The cultivation mechanism of green technology innovation in manufacturing industry: From the perspective of ecological niche. J. Clean. Prod. 2020, 252, 11. [CrossRef]

11. Lin, Y.; Zhao, H.X.; Yu, F.; Yang, J.F. Design of an extended experiment with electrical double layer capacitors: Electrochemical energy storage devices in green chemistry. Sustainability 2018, 10, 10. [CrossRef]

12. Tseng, T.-L.B.; Chiou, R.; Mandal, P.; Smith, E.D.; Belu, R.G.; Salcedo, O.H. Fusing green energy into manufacturing engineering education to cultivate technical success. In Proceedings of the 2014 ASEE Annual Conference, Indianapolis, 15-18 June 2014.

13. Pei, Z.J.; Zhang, P. Inclusion of green energy manufacturing contents in an introductory course on manufacturing processes and systems. In Proceedings of the 2011 ASEE Annual Conference \& Exposition, Vancouver, BC, Canada, 26-29 June 2011.

14. Narayanan, R.G.; Das, S. Sustainable and green manufacturing and materials design through computations. Proc. Inst. Mech. Eng. C J. Mech. Eng. Sci. 2014, 228, 1581-1605. [CrossRef]

15. Xiong, X.Q.; Ma, Q.R.; Yuan, Y.Y.; Wu, Z.H.; Zhang, M. Current situation and key manufacturing considerations of green furniture in China: A review. J. Clean. Prod. 2020, 267, 121957. [CrossRef]

16. Anthony, B. Examining the role of green IT/IS innovation in collaborative enterprise-implications in an emerging economy. Technol. Soc. 2020, 62, 101301. [CrossRef]

17. Gaikwad, L.; Sunnapwar, V. An integrated Lean, Green and Six Sigma strategies: A systematic literature review and directions for future research. Tqm J. 2020, 32, 201-225. [CrossRef] 
18. Fan-Hua, K.; Cheng-Li, H.; Chia-Ling, C. Assessing the green value chain to improve environmental performance: Evidence from Taiwan's manufacturing industry. Int. J. Dev. Issues 2012, 11, 111-128.

19. Yang, M.X.; Li, J.; Yu, I.Y.; Zeng, K.J.; Sun, J.M. Environmentally sustainable or economically sustainable? The effect of Chinese manufacturing firms' corporate sustainable strategy on their green performances. Bus. Strategy Environ. 2019, 28, 989-997. [CrossRef]

20. Glantschnig, W.J. Green design: An introduction to issues and challenges. IEEE Trans. Compon. Packag. Manuf. Technol. Part A 1994, 17, 508-513. [CrossRef]

21. Zhang, L.; Hongwei, P.; Zhifeng, L.; Hong, B.; Benyang, B. Knowledge reuse in green product concept design process. J. Mech. Eng. 2013, 49, 72-79. [CrossRef]

22. Wong, J.K.W.; Zhou, J. Enhancing environmental sustainability over building life cycles through green BIM: A review. Autom. Constr. 2015, 57, 156-165. [CrossRef]

23. Handoko, F.; Paula, C.; Hidayat, S.; Rastini, E.K.; Wijayaningtyas, M.; Vitasari, P. A green-based manufacturing system to solve pallet shortage problems. Heliyon 2021, 7, e06823. [CrossRef]

24. Yimeng, L.; Yu, X. Research trend of green design. Key Eng. Mater. 2014, 572, 16-19.

25. Li, J.K.; Zhang, J.; Gao, Z.H.; Chen, Q.; Liu, Z.X. An evaluation system of ecology-safe and environment-friendly society-Green production system. Bulg. Chem. Commun. 2017, 49, 107-112.

26. $\mathrm{Wu}, \mathrm{X}$.-Z.; Zhang, H. Green production process implemented architecture for manufacturing enterprises. Comput. Integr. Manuf. Syst. 2010, 16, 70-75.

27. Setyaningsih, I.; Ciptono, W.S.; Indarti, N.; Kemal, N.I.V. What is green manufacturing? A quantitative literature review. E3S Web Conf. 2019, 120, 01001. [CrossRef]

28. de Alba, J.M.; Todorov, V. How green is manufacturing? Status and prospects of national green industrialisation. The case of Morocco. Int. J. Innov. Sustain. Dev. 2018, 12, 308-326. [CrossRef]

29. Bhattacharya, A.; Nand, A.; Castka, P. Lean-green integration and its impact on sustainability performance: A critical review. J. Clean. Prod. 2019, 236, 117697. [CrossRef]

30. Hallam, C.; Contreras, C. Integrating lean and green management. Manag. Decis. 2016, 54, 2157-2187. [CrossRef]

31. Amrina, U.; Zagloel, T.Y.M. The harmonious strategy of lean and green production: Future opportunities to achieve sustainable productivity and quality. In Proceedings of the 6th IEEE International Conference on Industrial Engineering and Applications (ICIEA), Tokyo, Japan, 12-15 April 2019; pp. 187-192.

32. Sangwan, K.S.; Mittal, V.K. A bibliometric analysis of green manufacturing and similar frameworks. Manag. Environ. Qual. 2015, 26, 566-587. [CrossRef]

33. Jiang, Z.G.; Ding, Z.Y.; Zhang, H.; Cai, W.; Liu, Y. Data-driven ecological performance evaluation for remanufacturing process. Energy Convers. Manag. 2019, 198, 111844. [CrossRef]

34. Binshi, X.; Shiyun, D.; Sheng, Z.; Peijing, S. Prospects and developing of remanufacture forming technology. J. Mech. Eng. 2012, 48, 96-105.

35. Liu, C.H.; Zhu, Q.H.; Wei, F.F.; Rao, W.Z.; Liu, J.J.; Hu, J.; Cai, W. A review on remanufacturing assembly management and technology. Int. J. Adv. Manuf. 2019, 105, 4797-4808. [CrossRef]

36. Binshi, X.; Enzhong, L.; Handong, Z.; Fan, S.; Peijing, S. The remanufacturing industry and its development strategy in China. Strateg. Study CAE 2017, 19, 61-65.

37. Matsumoto, M.; Yang, S.S.; Martinsen, K.; Kainuma, Y. Trends and research challenges in remanufacturing. Int. J. Precis. Eng. 2016, 3, 129-142. [CrossRef]

38. Zlamparet, G.I.; Ijomah, W.; Miao, Y.; Awasthi, A.K.; Zeng, X.L.; Li, J.H. Remanufacturing strategies: A solution for WEEE problem. J. Clean. Prod. 2017, 149, 126-136. [CrossRef]

39. Binshi, X.; Shiyun, D.; Peijing, S. States and prospects of China characterised quality guarantee technology system for remanufactured parts. J. Mech. Eng. 2013, 49, 84-90.

40. Zhang, X.G.; Zhang, M.Y.; Zhang, H.; Jiang, Z.G.; Liu, C.H.; Cai, W. A review on energy, environment and economic assessment in remanufacturing based on life cycle assessment method. J. Clean. Prod. 2020, 255, 19. [CrossRef]

41. Lewandowska, A.; Foltynowicz, Z. New direction of development environment life cycle assessment. Pol. J. Environ. Stud. 2004, $13,463-466$.

42. Xue, M.Q.; Xu, Z.M. Application of life cycle assessment on electronic waste management: A review. Environ. Manag. 2017, 59, 693-707. [CrossRef] [PubMed]

43. Zhou, Z.Z.; Tang, Y.J.; Chi, Y.; Ni, M.J.; Buekens, A. Waste-to-energy: A review of life cycle assessment and its extension methods. Waste Manag. Res. 2018, 36, 3-16. [CrossRef] [PubMed] 